\title{
Ethnochemistry in the Chemistry Curriculum in Higher Education: Exploring Chemistry Learning Resources in Sasak Local Wisdom
}

\author{
Hari Sutrisno ${ }^{1, *}$, Dwi Wahyudiati ${ }^{2}$, Isana Supiah Yosephine Louise ${ }^{1}$ \\ ${ }^{1}$ Department of Chemistry Education, Faculty of Mathematics and Educational Sciences, Universitas Negeri Yogyakarta, Yogyakarta \\ 55281, Indonesia \\ ${ }^{2}$ Department of Chemistry Education, Fakultas Tarbiyah dan Keguruan, Universitas Islam Negeri Mataram, Mataram 8316, Indonesia
}

Received September 4, 2020; Revised November 6, 2020; Accepted November 19, 2020

\begin{abstract}
Cite This Paper in the following Citation Styles
(a): [1] Hari Sutrisno, Dwi Wahyudiati, Isana Supiah Yosephine Louise, "Ethnochemistry in the Chemistry Curriculum in Higher Education: Exploring Chemistry Learning Resources in Sasak Local Wisdom," Universal Journal of Educational Research, Vol. 8, No. 12A, pp. 7833-7842, 2020. DOI: 10.13189/ujer.2020.082572.
\end{abstract}

(b): Hari Sutrisno, Dwi Wahyudiati, Isana Supiah Yosephine Louise (2020). Ethnochemistry in the Chemistry Curriculum in Higher Education: Exploring Chemistry Learning Resources in Sasak Local Wisdom. Universal Journal of Educational Research, 8(12A), 7833-7842. DOI: 10.13189/ujer.2020.082572.

Copyright $\bigcirc 2020$ by authors, all rights reserved. Authors agree that this article remains permanently open access under the terms of the Creative Commons Attribution License 4.0 International License

\begin{abstract}
Understanding the concept of chemistry can not only be done directly by studying chemistry, but even chemistry will also be more easily understood if contextualized with culture, because the concept of chemistry is very analogous to culture (Ethnochemistry). This paper will discuss Ethnochemistry in the local wisdom of the Sasak tribe, West Nusa Tenggara, Indonesia contained in the Merarik (wedding) tradition. In this tradition, there are social, moral and spiritual values such as the concept of giving and receiving, cooperation, mutual respect, and the concept of a mutual need to achieve stability. These concepts have very strong relevance to the theory of chemical bonds which includes the concept of electron stability, electron configuration, positive and negative ions, and the theory of chemical bond formation so that it can be concluded the theory of chemical bonds has interconnection with local wisdom of Sasak tribe (Ethnochemistry). The concept of material and its changes integrated into local Sasak wisdom are reflected in the use of chemical elements from various types of metals such as gold, silver, bronze, copper, brass, and various other metals for the manufacture of traditional ceremonial tools and traditional Sasak arts. Likewise, the concept of material change is found in food processing, traditional art tools and cultural products of the Sasak tribe. Thus the application of ethnhochemistry in chemistry learning can act as a natural laboratory \& learning media so as to make chemistry
\end{abstract}

learning more enjoyable and relevant to students' daily lives (contextual-based learning).

Keywords Ethnochemistry, Chemistry Curriculum, Sasak Local Wisdom, Learning Resources

\section{Introduction}

Ethnochemistry is a variety of cultural practices that describe the chemical practices of cultural groups that are chemically related and can be identified as studies of chemical ideas that can be found in any culture [1]. In addition, ethno refers to group members in cultural environments identified by cultural traditions, codes, symbols, and myths to consider and conclude concepts [2]. The use of cultural products as learning resources has a positive influence on student learning outcomes, as previous research shows that the use of cultural products as learning resources has an influence on improving students' abilities [3]. Research related to Ethnochemistry also has an effect on improving student scientific attitudes [4] and also a positive response to human rights [5]. Likewise, with the tradition of Merarik the Sasak tribe has very strong relevance to the theory of chemical bonds so that it can be used as a learning resource that can facilitate 
students to understand the material of chemical bonds (contextual learning).

The philosophy and basic principles of the Merarik tradition in the Sasak tribe such as the concept of giving and receiving, cooperation, mutual respect, and the concept of a mutual need to achieve stability have strong relevance to the theory of chemical bonds. These philosophies and principles are directly related to the theory of chemical bonds such as; the concept of stable electron/electronic configuration is stable, the concept of positive ions and negative ions, the theory of chemical bond formation, inter-atomic bonds consisting of ionic bonds, polar covalent bonds, non-polar covalent bonds, covalent coordination bonds, metal bonds, bonds between molecules consists of the theory of the formation of hydrogen bonds and Van der Waals bonds [6]. Based on the explanation above, it is very important to conduct the Etnochemistry study to integrate chemistry with local wisdom from certain communities. The aim is to make it easier for students to understand chemical concepts, as well as efforts to preserve cultural heritage.

As for Basic Chemistry I material that has relevance to Sasak local wisdom, namely, chemical bonds, substances and materials, the periodic system of elements, and atomic structure. In general, the local wisdom values contained in this tradition are the concepts of mutual giving and receiving, mutual need, social solidarity, compassion, and cooperation. These local wisdom values have very deep relevance to the concept of chemical bond theory which is studied or analyzed from various viewpoints of chemical bond theory such as the concept of electron stability, stable electron configuration, and the theory of chemical bond formation. However, the integration of ethnochemistry with the curriculum, learning tools and in the preparation of teaching materials is still very rare $[7,8,9,10]$. This has an impact on students' ability to understand the concepts of matter and matter, atomic structure, the periodic system of elements, and low chemical bonds and lead to misconceptions [8]. One of the best solutions to solve these problems with ethnochemical integration in the curriculum must be placed in the context of student life with cultural heritage as the substance of scientific investigation (natural laboratories) $[11,12,13$, $14,15]$, so that through the integration of Basic Chemistry 1 material with Sasak local wisdom that has been it has never been done, it is hoped that it can support the effective implementation of 21 st century learning.

Efforts to link chemistry learning with local culture, especially Sasak culture, are very urgent to do as an alternative in linking Basic Chemistry 1 chemistry with the context of student life that is reflected in the practice of daily life or Sasak cultural heritage. In addition, the form of culture as physical culture in the form of artifacts, handicrafts and traditional arts of the Sasak tribe can be used as a natural laboratory that can directly observe the phenomena that occur related to chemical concepts that are found in everyday life so that it has a positive impact on increasing understanding of concepts, attitudes, scientific skills, morals, and spiritual values needed by students to be able to compete in the face of the industrial revolution era 4.

\section{Research Methods}

The research method used is qualitative research with data collection techniques through observation, in-depth interviews, documentation, and curriculum analysis. Data collection activities were carried out by exploring local Sasak wisdom which could be used as a learning resource in Basic Chemistry course 1 by referring to the etnhochemistry approach.

Study of literature activities that have been carried out include; (a) identifying the competencies that students must achieve in learning chemistry in higher education, (b) analyzing the implementation of chemistry learning in higher education, (c) analyzing the relevance of Sasak cultural local wisdom with chemistry learning, (d) analyzing the relevance of Sasak local wisdom with the model problem-based learning (PBL model), (e) analyzing the relevance of Sasak local wisdom with Basic Chemistry 1 material, (f) identifying student characteristics, (g) analyzing the urgency of developing student scientific attitudes \& science process skills, and (g) analyzing research results relevant as a theoretical study to support the results of the research conducted.

The data obtained at this stage is in the form of qualitative data and is analyzed using qualitative data analysis techniques proposed by Miles \& Huberman, which consists of three stages, namely data reduction, data presentation (data display), and drawing a conclusion (conclusion drawing). The data analysis activity was continued with the analysis of content, values, learning outcomes, and competencies that must be achieved by chemistry education students at the tertiary education level in Indonesia.

\section{Results and Discussion}

\section{The relevance of Basic Chemistry 1 with Sasak Local Wisdom in terms of Analogy, Representation, Apperception, Visualization and Interpretation Perspective}

Cultural forms are grouped into 3 forms [26], namely; (1) the form of culture as an idea, idea, value or norm; (2) the form of culture as a social system is an activity or pattern of human action when interacting in community life; and (3) cultural forms in physical form which are objects of human work that are concrete or tangible (artifacts, handicrafts, and arts). Referring to the three forms of culture, Basic Chemistry 1 has a close relationship with the local wisdom of Sasak culture in 
terms of analogy, representation, perception, visualization, and interpretation that can be applied during learning so that it makes it easier for students to understand the concept of chemistry with cultural utilization as a natural laboratory.

The concept of analogy is a way of relating a comparative relationship to a concept that has linkages between concepts to explain a related meaning [27]. In addition, the analogy is a correspondence relationship between two different domains that have the same meaning (analog domain). The analog domain is a domain that resides in memory and contains an analogous representation of the analogous target [28]. The concept of analogy is a process of transferring information from analog to target with the main procedure of finding the correspondence between two analog systems [29]. The two concepts have different domains but have a relevant meaning (metaphorical analogy between domains). For example, the use of examples of everyday life situations that are analogous to chemical concepts is called interdomain analogy [30]. The relevance of the analog domain concept allows students to construct knowledge and experiences independently and involves students to analyze the knowledge gained through the analogy process [31].

The application of the analogy approach can make it easier for students to understand specific concepts, develop problem-solving skills, and integrate new knowledge and experiences gained with previous knowledge [32]. The results of previous research also prove that the application of analogical concepts in learning is very effective in helping students to understand concepts that are relevant to everyday life associated with abstract chemical materials such as the form of organic compounds, atomic structure, and types of chemical bonds [27]. In addition, the application of analogy in learning makes learning more interesting, less boring, and contextual $[33,41]$.

The relevance of Basic Chemistry 1 material to Sasak local wisdom is also viewed from the representation approach which is a chemical characteristic consisting of microscopic, macroscopic, and symbolic components [38]. The complex and abstract chemical nature makes learning and teaching difficult for students and teachers [39]. Thus, conceptual understanding in chemistry includes the ability to represent and translate chemical problems using macroscopic (observable), microscopic (particulate), and symbolic representational forms [40]. Based on the results of research conducted by Gabel \& Samuel [41], it is evident that chemical phenomena studied at the macroscopic level can also be studied at the sub-microscopic level, as well as the symbolic level to solve complex problems. Therefore, a good understanding of chemistry requires the ability to integrate these levels and is the biggest challenge in learning chemistry so that students often have difficulty connecting the different levels of representation and become a major obstacle to learning [38, 39]. One alternative solution in overcoming these problems is through the use of visual tools in improving visualization skills and understanding representation by using images, concrete or real models, photos, graphics, diagrams, computational programs, integrating concepts with the culture of an area which has a positive impact on student learning outcomes [41, 42, 43, $44,45,46]$.

\section{Ethnochemistry: Relevance of the Chemical Bonds to the Local Wisdom of the Sasak Tribe}

The relevance of the chemical bond theory concept to Sasak local wisdom is scientifically viewed from the perspective of analogy between domains. The analogy is a way of expressing a comparative relationship between two or more concepts that are related to each other by referring to the relationship between concepts in explaining a relevant meaning [27]. In addition, the analogy is known as the system of relations (correspondence) which is owned between the structure of the two domains (analog domains). The analog domain (source or base domain) is the domain that is in memory, which represents the analogy which is then drawn and contains an analogous representation of the target [28]. An analogy involves the transfer of relational (structural) information from analog to the target, the transfer of which is carried out by the process of mapping or matching, which consists of finding the correspondence between two systems [29]. The two systems may belong to different domains, but have the same explanatory structure (inter-domain analogy or metaphorical). For example, the use of examples of solved problems to find ways of solving other similar problems, as well as using everyday life situations as analogs in chemical treatments or inter-domain analogies [35]. The familiarity and affinity of the analog domain support the mapping of elements from the two domains and allows students to construct and examine their own knowledge, by engaging them to view and examine their knowledge through the analogy process [31]

The application of the analogy approach is able to develop students' understanding of specific concepts used in analogies, identify and analyze relationships between concepts, develop critical thinking skills, and help students connect new information with existing knowledge [32]. Teaching with analogs enables students to be active in the learning process, helps students connect new information with previous knowledge, to integrate information for one subject to another, and to relate classroom information to everyday experiences. The results of previous research also emphasized that analogies support learning that approaches and help students to build topics easily, such as abstract concepts on nomenclature, forms of organic compounds, and types of organic bonds [27]. On the other hand, the application of analogy is very pleasing to students, which makes learning more interesting and less boring [33]. A fun learning process is a very important factor in supporting 
the achievement of effective learning.

The relevance of the chemical bond theory concept to Sasak's local wisdom is scientifically viewed from the perspective of inter-domain analogy, which is based on the concept of electron stability / stable electronic configuration, the concept of positive ions and negative ions, and the theory of chemical bond formation. Based on the traditional wedding procession (merarik) which is the local wisdom of the Sasak tribe of Lombok which is most closely related to the theory of chemical bonds. The relationship between the tradition of pulling with chemical bonds in terms of analogy perspective, namely the existence of similarities in the theory or concept that underlies it, and the meanings and values contained therein [36]. At the nenarih (applying) event, especially when there is an agreement between the girl and the young man to get married, whether it is asked by the young man himself or through his subandar or shout (male representative). The underlying concept is the concept of mutual need, mutual giving, and receiving to live together, with the bonding relationship, namely a marriage relationship through the marriage contract process [22]. In chemical bond theory, the concept that underlies the formation of chemical bonds is the concept of giving and receiving an atom to achieve a stable electron configuration [37]. Atoms can be bonded because the atoms that are bonded are more stable than atoms in separate states. The tendency of an atom to achieve this stability can occur by forming chemical bonds between one atom and another. Atoms that are close to the noble gas configuration will try to achieve the noble gas configuration either by accepting or giving away their outer shell electrons so that positive and negative ions are formed by transferring electrons from one atom to another [37], for example, an unstable sodium atom releases one electron to become a $\mathrm{Na}^{+}$ion in an electronic configuration such as neon. The $11 \mathrm{Na}$ atom ${ }_{11} \mathrm{Na}(2.8 .1)$ $\rightarrow$ Ion ${ }_{11} \mathrm{Na}^{+}$(2. 8) (2.8. 1), while the unstable $\mathrm{Cl}$ atom receives an additional electron, thus becoming a $\mathrm{Cl}^{-}$ion with an electronic configuration such as argon. $17 \mathrm{Cl}$ atom ${ }_{17} \mathrm{Cl}$ (2. 8. 7) $\rightarrow$ Ion ${ }_{17} \mathrm{Cl}^{-}(2.8$. 8). These two ions with opposite charges attract each other electrostatically in the ion lattice. The handover of electrons that occurs from the joining of the two atoms above is called an ionic bond. The concept of ionic bonds is very closely related to the tradition of merarik (marriage) in the Sasak tribe because the concept of merarik (marriage) in the Sasak tribe is also based on the principle of mutual need and complementarity to achieve one goal that not only unites two individuals but essentially unites two families in a bond known as besan or the man's family relationship with the woman [36]. In addition, the interaction between two or more atoms is always accompanied by an expenditure of energy. The concept of energy expenditure in the chemical bonding theory is analogous to the existence of the ajikrama tradition (the amount of customary payments), where the submission of all customary payments is carried out in a ceremony called sorong serah [22]. The force that holds the atoms in the molecule is called chemical bonding [37]. Chemical bonds are the forces or interactions that cause atoms to bond together as molecules or cause atoms, ions, and molecules to bond together as more complex collections.

Merarik in the Sasak dictionary means marriage [10] as shown in Figure 1. Merarik in the Sasak dictionary means marriage [10]. Merarik in the Sasak community is done in two ways, namely memaling (eloping bride candidate) and belako' (proposing). Part of the procession Merarik in the Sasak community which has strong relevance to the theory of chemical bonding is a tradition known as the Sorong serah (dowry submission) and Nenarih (proposing) or Beketoan (questioning). The connection between these two activities with the theory of chemical bonds is on the equation of the theory or concept underlying it, the meaning, and the values contained in it. In the procession Nenarih, this connection can be found in building an agreement between a girl and a young man to get married [16]. The concept that underlies the agreement is a sense of mutual need, mutual giving, and mutual acceptance to live together. The bond to live together between a girl and a man is done through the marriage process [17]. The Sorong serah is carried out through traditional ritual ceremonies to hand over the bride to the groom's family, which marks the transfer of responsibility from the bride's family to the bridegroom as shown in Figure 2. The Sorong serah is carried out through traditional ritual ceremonies to hand over the bride to the groom's family, which marks the transfer of responsibility from the bride's family to the bridegroom. The philosophy that underlies the Sorong serah ritual is very analogous to the concept of ionic bonds, namely the handover of electrons between positive ions and negative ions to achieve stability, such as the formation of Sodium Chloride, $\mathrm{NaCl}$.

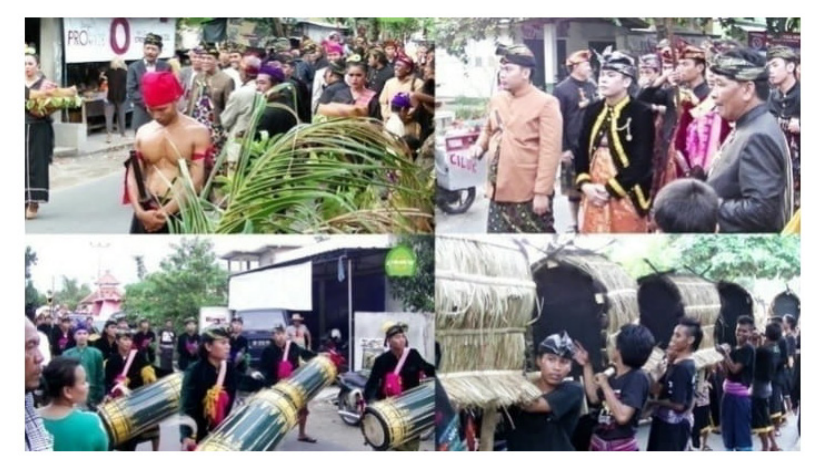

Figure 1. Merarik tradition (wedding) of the Sasak tribr

In the theory of chemical bonds, the concept underlying the formation of chemical bonds is the concept of giving and receiving electrons between atoms to achieve a stable electronic configuration [18] because atoms that have bonded with other atoms will be more stable than the stand-alone atoms [19].

The tendency of an atom to achieve stability can occur 
by forming chemical bonds between one atom and another [15]. The bond is carried out to achieve a noble gas configuration by accepting or releasing electrons from the outer shell that is owned so that positive and negative ions are formed by transferring electrons from one atom to another. For example an unstable Sodium atom releases one valence electron so that positive ions $\left(\mathrm{Na}^{+}\right)$are formed with electron configurations such as neon; Atom $11 \mathrm{Na}(2.8 .1) \rightarrow$ Ion $11 \mathrm{Na}^{+}(2.8)$ while unstable $\mathrm{Cl}$ atoms receive extra electrons so that negative ions $\left(\mathrm{Cl}^{-}\right)$are formed with electron configurations such as argon; Atom $17 \mathrm{Cl}$ (2. 8. 7) $\rightarrow$ Ion $17 \mathrm{Cl}^{-}$(2. 8. 8) as shown in Figure 3. The formation of chemical bonds through the handover of electron pairs between positive ions and negative ions to achieve electronic stability is called ionic bonds [20].

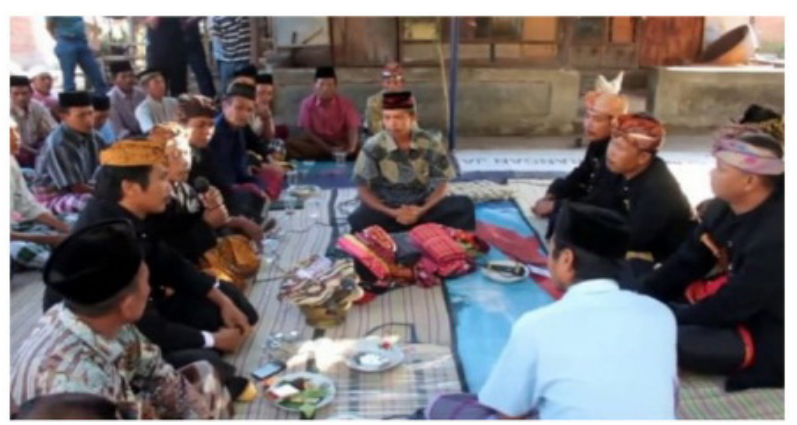

Figure 2. Sorong serah ceremony (dowry submission) in the Merarik tradition
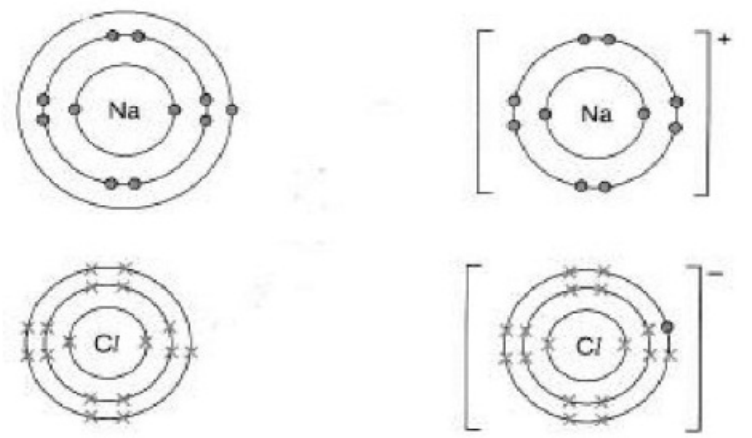

Figure 3. Handover of electrons in the formation of sodium chloride compound, $\mathrm{NaCl}$
Not only is the concept of ion bonds related to the tradition of Merarik the Sasak tribe, but it is also related to the concept of forming metal bonds in the theory of chemical bonds formed by the attractive attraction that occurs between the positive charge of metal ions and the charge negative of free-moving electrons [21]. As for the relevance of the tradition of Merarik, especially in Nenarih activities, a girl is given the opportunity to give her own decisions without coercion from anyone. Submission of questions in nenarih activities can be done directly by the prospective husband or through $a$ Subandar (delegation) or Jerumannya (youth body in the community) [22]. The aim is to clarify the status of the girl who is currently not promising another man to marry her. Furthermore, after obtaining certainty from the girl, it is determined when the girl will be taken to the prospective groom's house.

Usually, in the tradition of Kawin lari (eloping bride candidate) in the Sasak tribe, which picks up the girl to be rushed (te paling) beside the groom, it is also accompanied by several men and women. Next, the girl who will be rushed is waiting outside the house. If the girl is successfully taken without interference, the girl is hidden in someone else's house, usually in the place of family members, not in the prospective husband's house. This is known as the 'Sebo' tradition (hiding the bride candidate).

In addition, the interaction between two atoms or more is always accompanied by energy expenditure. The concept of energy expenditure on the theory of chemical bonding has a strong relationship with the existence of the Ajikrama tradition (number of customary payments or related fee), in which the surrender of all customary prices is carried out in a ceremony called Sorong serah. The force that holds atoms in a molecule is called a chemical bond. Chemical bonds are forces or interactions that cause atoms to be bonded together as molecules or cause atoms, ions, and molecules to be bonded together as more complex and stable bonds [23]. 
Table 1. Ethnochemistry in Sasak local wisdom

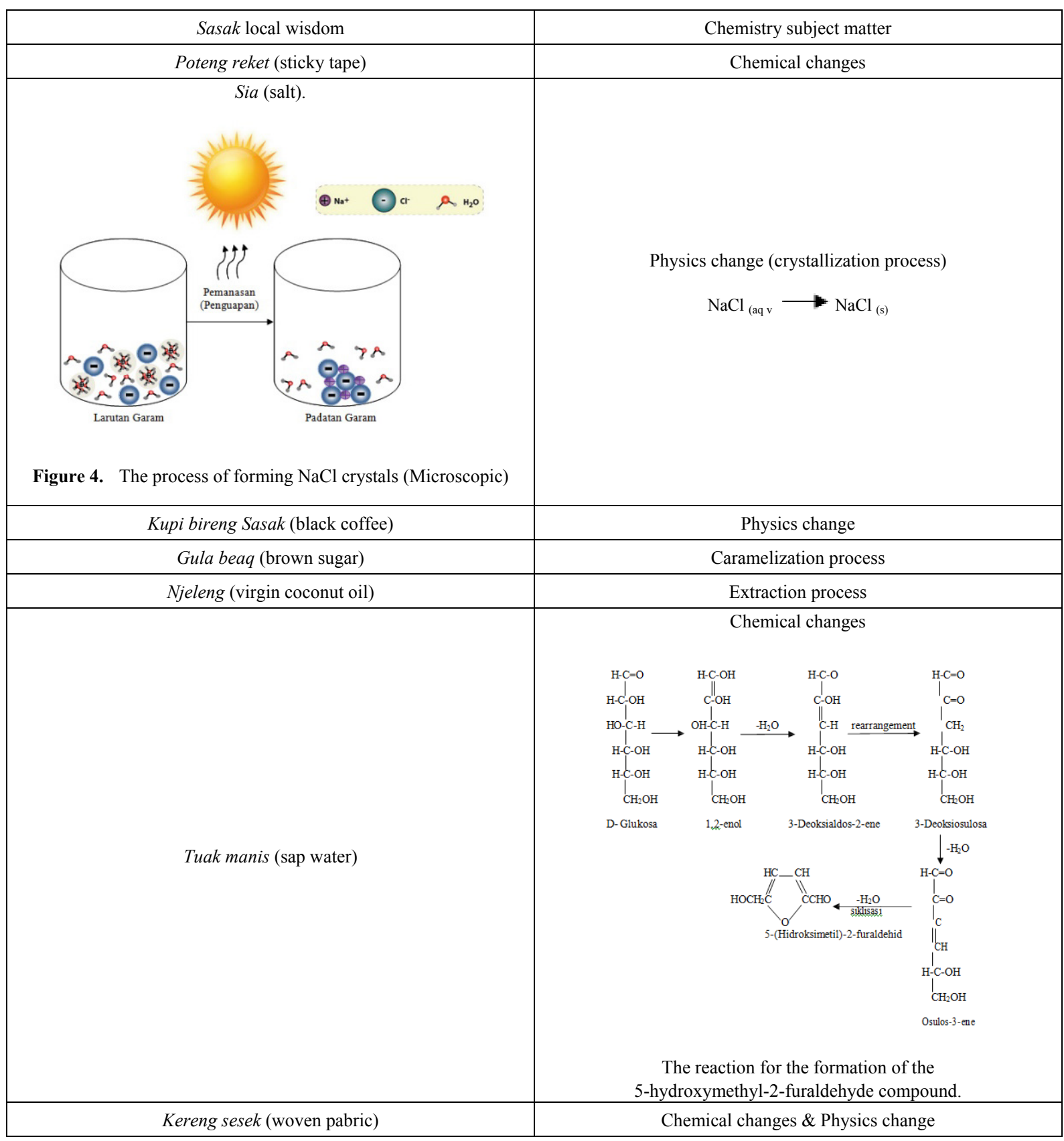

\section{Ethnochemistry: The relevance of the subject matter and its changes to local Sasak wisdom}

The concept of material and its changes integrated into local Sasak wisdom is reflected in the use of chemical elements from various types of metals such as gold, silver, bronze, copper, brass, and various other metals for the manufacture of traditional ceremonial tools and traditional Sasak arts. For example, the Sasak bride's jewelry is made of gold, silver, and bronze [22]. Compounds and mixtures are widely used in the life of the Sasak people, namely the manufacture of traditional art tools such as gongs, terumpang, kenceng and keris which are made from a combination of two or more metals [24]. Examples of physical changes found in local Sasak wisdom include the making of sia or salt, making Sasak kupi bireng (black coffee), and the tradition of belulut (coating the floors of traditional Sasak houses with cow dung). Examples of chemical changes are found in making gula beaq (brown sugar), making poteng reket (sticky tape), poteng ambon (tape sweet potato), and kereng sesek (typical Sasak woven cloth). In the Sasak people, the technique of separating the mixture with crystallization techniques has been carried out from generation to generation and is still ongoing today, among others; in the process of making sia or salt by processing seawater, and for the manufacture of 
beaq sugar or brown sugar from sap water. Sasak local wisdom that applies the principle of extraction is found in the manufacture of virgin coconut oil which is known in the Sasak tradition as "njeleng". The tradition of njeleng (making virgin coconut oil) is still ongoing today, especially when religious or traditional ceremonies are held such as ngawinan (wedding parties), nyunatan (circumcision), begawe (hajatan), and various other traditional ceremonies [22]. Local Sasak wisdom regarding the njeleng process, namely the manufacture of traditional Sasak medicinal oil known as "oat mandi" (a very potent medicine). This bath oat is made by certain people who are considered to have supernatural advantages and in the manufacturing process, it is preceded by a sacred ceremony (recitation of prayers). The ingredients of this medicinal concoction are only known by supernatural figures known as "belian Sasak" or shaman [25]. This oat mandi (a very potent medicine) is believed to be very effective in treating wounds. The results of ethnochemistry analysis in local Sasak wisdom are summarized in the following table 1 .

In the Lombok Sasak tribe community, the use of various types of metal as an example of an element is reflected in the traditional ceremonial tools and traditional arts owned by the Sasak Lombok tribe, including:

\section{(1) Tools for Traditional Ceremonies;}

According to the traditions of the Sasak people, traditional ceremonial tools are objects that are considered sacred and have certain philosophical meanings. In the making of these ceremonial tools, many use metal elements such as gold, copper, iron, brass, and several other types of metal, as the following description. Keris is one of the objects that is considered sacred and is usually used during wedding ceremonies of the Sasak Lombok tribe, NTB.

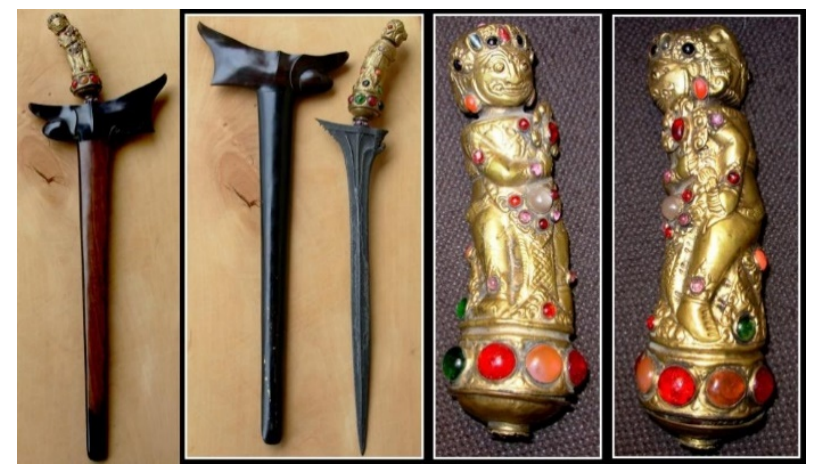

Figure 4. Keris

The handle of the keris for the nobility is usually made of gold $\mathrm{(Au}$ ) elements. Gold has an atomic number of 79 . The arrangement of the outer electrons of gold is related to the yellow color property of gold. Metal colors are formed based on the transition of electrons between energy bonds. The ability to absorb light at this wavelength to produce a distinctive gold color occurs due to the d-bond transition which releases the position in the conduction bond. Gold is considered a precious and precious metal. The chemical features of gold are shown by the stability of its chemical elements which can with stand rust and oxidation processes. Element $\mathrm{Au}$ (gold) crystallizes in the cubic face-centered (fcc) form as shown in Figure 5.

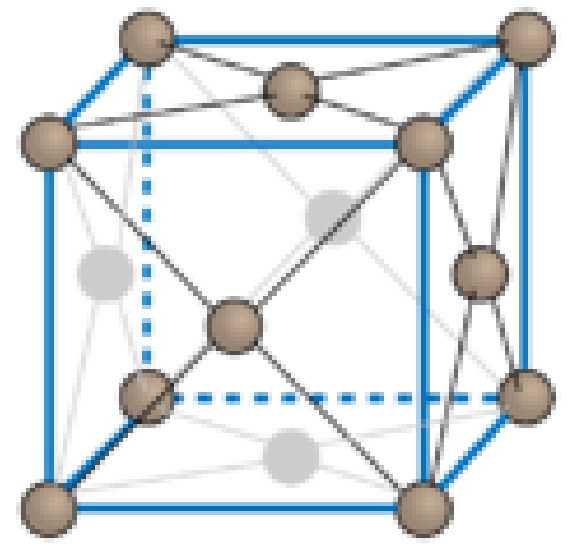

Figure 5. Cubic face-centered (fcc) structure

(2) Traditional Art Tools; One of the traditional Sasak art tools that make use of zinc ( $\mathrm{Zn})$ as an ingredient and is known as "gula gending". This art tool is used by the Sasak people in selling gula gending (cotton sugar), where the sound emitted from this tool aims to attract the attention of buyers. The element zinc $(\mathrm{Zn})$ has an atomic number of 30 and a mass number and a relative atomic mass of 65.39. Zinc is a metal that is bluish-white, lustrous and is diamagnetic. Zinc is capable of conducting electricity and compared to other metals it has relatively low melting points $\left(420^{\circ}\right.$ C) and boiling points $\left(900^{\circ} \mathrm{C}\right)$. Likewise, the melting point of zinc is the lowest of all the transition metals apart from mercury and cadmium. Zinc is slightly less dense than iron and has a hexagonal crystal structure as shown in Figure 6.

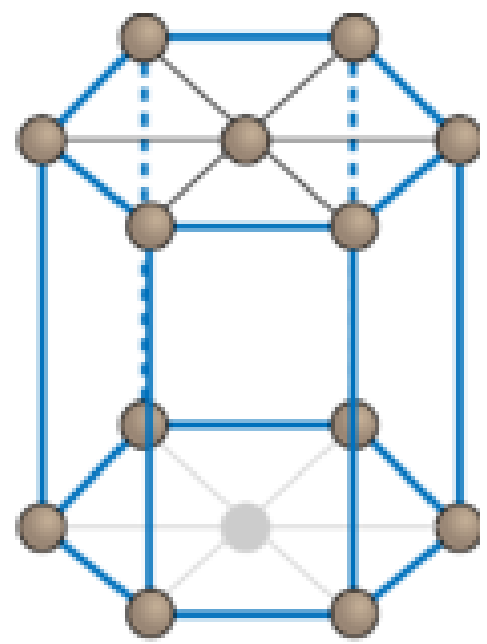

Figure 6. hexagonal crystal structure 


\section{Application of Ethnochemistry in Chemical Learning}

Learning the concept of chemical bonds can be done by integrating the tradition of Merarik with the concept of chemical bonds (Etnochemistry) in learning. First, students are asked to identify compounds found in daily life and discuss them in groups. Then each group was asked to choose salt or water compounds to analyze the types of bonds that make up that compound. The activity continued with presentations from each group to explain the concept of ionic bonds (surrender of electron pairs, the formation of positive and negative ions) in salt compounds, and the concept of covalent bonds (shared use of electron pairs) in water compounds to achieve a stable electronic configuration. Furthermore, through videos or pictures, traditional Merarik ceremonies (Nenarih and Sorong serah) from the Sasak tribe are displayed. Furthermore, students with teacher guidance analyze the relevance of tradition Merarik with ionic and covalent bonds based on the concept of analogy. The expected conclusion is that students know the basic principles of the Merarik tradition (Nenarih and Sorong serah) of the Sasak tribe is very analogous to the principle of ionic and covalent bonding based on the principle of mutual need, the concept of giving and receiving, and the cooperation to achieve stability. In this case, Etnochemistry is used as a source of learning in studying chemistry, meaning understanding chemical concepts through everyday life experiences (contextual learning) so that learning will be more interesting and challenging for students. The activity continued with students conducting individual or paired investigations related to chemical ideas in Etnochemistry. Ideas must be established through class discussions with teacher guidance so that can give students the opportunity to develop chemical knowledge independently (student-centered learning).

\section{Conclusions}

1. The chemical bond theory has relevance to the tradition of Merarik the Sasak tribe, Lombok, West Nusa Tenggara, Indonesia namely the tradition of Nenarih and Sorong serah.

2. The values of the local wisdom of the Sasak Lombok tribe are strongly related to the concept of chemical bonds reviewed in terms of philosophical values and analogies namely the concept of positive and negative ions, stable electron configuration, the theory of chemical bond formation, ionic and covalent bonds, metal bonds, hydrogen bonds and Van der Waals bonds.

3. The moral, social and spiritual values contained in the local wisdom of the tradition of Merarik are closely related to the basic principles of the theory of chemical bonds, namely the concept of mutual need, mutual giving and receiving in order to achieve stability, tolerance, social solidarity, and the value of cooperation to achieve stability, peace, tranquility and shared prosperity.

4. Compounds and mixtures are widely used in the life of the Sasak people, namely the manufacture of traditional art tools such as gongs, terumpang, and kenceng which are made from a combination of two or more metals.

5. Examples of physical changes found in local Sasak wisdom include dyeing Sesek cloth, making sia or salt, and the tradition of belulut (coating the floors of traditional Sasak houses with cow dung). Examples of chemical changes are found in making beaq sugar, making poteng reket (sticky tape), and coloring Sesek fabrics.

6. The application of Ethnochemistry in chemistry learning can be used as a learning resource and instructional Media so learning will be more interesting and challenging for students (Contextual learning).

\section{REFERENCES}

[1] Singh, I. S, "Effect of Ethnochemsitry Practice on Secondary Schools Structure Attitude toward Chemistry", Journal of Education and Practice, vol. 7, no. 17, pp. 44-56, 2016. https://carijournals.org/journals/JEP

[2] Rosa, M. \& Orey, D. C, "Ethnomathematics: the cultural aspects of mathematics", Revista. Latinoamericana de Etnomatemática, vol. 4, no. 2. Pp. 32-54, 2011. http://www.redalyc.org /articu lo.

[3] Sochima, Unodiaku, "Effect of Ethno-Mathematics Teaching Materials on Students'Achievement in Mathematics in Enugu State", Journal of Education and Practice, vol. 4, no. 23, pp. 70-77, 2013. https://carijournals.org/journals/index.php/JEP

[4] Ador., \& Said, N., K, "Ethnochemistry of maguindanaos on the usage house hold chemicals: implication to chemistry education", Journal of Social Sciences (COES\&RJ-JSS), $\begin{array}{lllll}\text { vol. } 6, \quad \text { no. } 2 . & \text { pp. } & 8-16, & \end{array}$ https://www.tandfonline.com/loi/rjss20.

[5] Abramova, I \& Greer, Al, "Ethnochemistry and Human Rights", Journal Chemsitry and Diversity, vol. 10, pp. 1724-1729, 2013. DOI: 10.1002/cbdv.201300211.

[6] Nell F Staff, Indonesian English Sasak Dictionary, Mataram: University Press, 1995, pp. 236.

[7] Tim Penelitian dan Pencatatan Kebudayaan Daerah, West Nusa Tenggara Regional Customs, Depdikbud, 1998, pp. 13-154.

[8] Wahyudiati, D., Sutrisno, H., \& Louise, I. S. Y, "Investigation of attitudes towards chemistry and learning experiences of pre-srvice chemistry teachers", MIER Journal of Educational Studies Trends \& Practices, vol. 9. no. 2, pp. 191-211, 2019. http://www.mierjs.in/ojs 
/index .php /mjestp.

[9] Fadli, A, "Problem solving skills and scientific attitudes of prospective teachers based on gender and grades level", International Journal of Scientific \& Technology Research, vol. 8, no. 10, pp. 3595-3599, 2019. http://www.ijstr.org.

[10] Wahyudiati, D., Sutrisno, H., \& Louise, I. S, "Self-eficacay and attitudes towards chemistry teachers: Gender and grades level perspective", International Journal of Scientific \& Technology Research, vol. 8, no. 9, pp. 1041-1044, 2019. http://www.ijstr.org.

[11] Fadli, A., \& Irwanto, "The Effect of Local Wisdom-Based ELSII Learning Model on the Problem Solving and Communication Skills of Pre-Service Islamic Teachers", International Journal of Instruction, vol. 13, no. 1, pp. 731-746, 2020. DOI: 10.29333/iji.2020.13147a.

[12] Wahyudiati, D., Rohaeti, E., Irwanto, Wiyarsi, A., \& Sumardi, L, "Attitudes toward chemistry, self-fficacy, and learning experiences of pre-service chemistry teachers: Grade level and gender differences", International Journal of Instruction, vol. 13, no. 1, pp. 235-254, 2020. DOI: 10.29333/iji.2020.13116a.

[13] Sumardi, L. \& Hanum, F, "Social Mobility and New Form of Social Stratification: Study in Sasak Tribe, Indonesia", International Journal of Scientific \& Technology Research, vol. 8, no. 10, pp. 708-712, 2019. http://www.ijstr.org.

[14] Sumardi, L., Rohman, A., \& Wahyudiati, D, "Does the Teaching and Learning Process in Primary Schools Correspond to the Characteristics of the 21st Century Learning?", International Journal of Instruction, vol. 13, no. 3, pp. 357-370, 2020.

[15] Erni, B, “Sasak Islam”, LkiS Yogyakarta, 2000, pp. 250-270.

[16] Widi, P, "Basic Chemistry 1", Cerdas Pustaka, 2009. pp. 161-170.

[17] Siregar, M, "Basics of Organic Chemistry", P2LPTK, 1988. pp. 150-180.

[18] Achamad, H. \& Tupamahu, M.S, "Atomic Structure, Molecular Structure, and Periodic System", PT. Citra Aditya Bakti, 2001, pp. 100-120.

[19] Baum, S. J \& Scaife, C. W. J, "Chemistry, A Life Science Approach", Macmillan Publishing, 1988, pp. 78-110.

[20] Wilbraham, C. Antony dan Matta, S. Michael, "Introduction to Organic and Biological Chemistry,", ITB, 1992, pp. 40-60.

[21] Wilbraham, C. Antony dan Matta, S. Michael, "Introduction to Organic and Biological Chemistry,", ITB, 1995, pp. 40-60.

[22] Tim Penelitian dan Pencatatan Kebudayaan Daerah, "West Nusa Tenggara Regional Customs”, Depdikbud, 1997/1998, pp. 153-154.

[23] Saito, T, "Inorganic Chemistry", permission of Iwanami Shoten Publishers, 1996, pp. 50-75.

[24] Djelenga, L, “Keris di Lombok. Mataram”, Yayasan Pusaka Selaparang, 2000, pp. 30-80.
[25] Boa, E. A., Wattanatorn, A., \& Tagong, K, "The development and validation of the blended socratic method of teaching (BSMT): An instruction model to enhance critical thinking skills of undergraduate business students", Kasetsart Journal of Social Sciences, vol. 39. No. 1. pp. 81-89, 2018. https://doi.org/10.1016/j.kjss.2018.01.001.

[26] Koentjaraningrat, "Pengantar ilmu antropologi", Rineka Cipta, 1986, pp. 60-80.

[27] Samara, N, "Effectiveness of using mind maps as teaching method on student's achievement in environmental education course at Mutah University", Journal of Mu'tah Lil-Buhuth wad-Dirasat, Humanities and Social Sciences Series, vol. 29, no. 3, pp. 97-124, 2013. https://ejournal.mutah.edu.jo/

[28] Dagher, Z.R., Thile, R.B., Treagust, D.F., \& Duit, R, "Comment on analogy, explanation, and education", Journal of Research in Science Teaching, vol. 30, pp. 615-617. 1993. https://onlinelibrary.wiley.com/journal.

[29] Vosniadou, S, "Analogical reasoning as a mechanism in knowledge acquisition: A developmental perspective", Cambridge University Press, 1989, pp. 80-100.

[30] Ango, M., L, "Mastery of science process skills and their effective use in teaching of science an educology of science education in the Nigerian context", International Journal of Educology, vol. 16, no. 1, pp. 11-30. 2002. http://www.ijeducology.eu/.

[31] Black, D., \& Solomon, J, "Can pupils use tought analogi for electric current?", School Science Review, vol. 69, pp. 247-254, 1987. https://www.ase.org.uk/resources.

[32] Kawthar, A. H, "The effect of analogy strategy in science teaching on scientific concepts acquisition and basic science processes skills", Damascus University Journal, vol.28. no. 2, pp. 411-451. 2012. http://www.damascusuniv ersity.edu.sy

[33] Lerman, Z. M, "Using the arts to make chemistry accessible to everybody", Journal of Chemical Education, vol. 80, pp. 1234-1243, 2003. DOI: 10.1021/ed080p1234.

[34] Miles, M. B., Huberman, A. M., \& Saldana, "Qualitative Data Analysis: A Method Sourcebook", Sage Publications, Inc, 2014, pp. 50-80.

[35] Johnstone, A. H. "Chemistry teaching-science or alchemy", Journal of Chemical Education, vol.74. no.3, pp. 262-268, 1997. https://doi.org/10.1021/ed074p262.

[36] Sukardjo, "Ikatan Kimia", Yogyakarta, 1990, pp. 70-90.

[37] Johnstone, A. H. "Chemical education research in Glasgow in perspective", Chemistry Education Research and Practice, vol.7. no.2, pp. 49-63. 2006. https://doi.org/10.1039/B5RP9 $0021 \mathrm{~B}$.

[38] Gabel, D. L., \& Bunce, D. M. "Research on problem solving: Chemistry”, In D. L. Gabel (Ed.), Handbook of Research on Science Teaching and Learning. New York: Macmillan, 1994, pp. 100-130.

[39] Gabel, A. D., \& Samuel, J. "Using analogies for chemistry problem solving: Does it increase understanding?", School Science and Mathematics, vol. 90, pp. 674-682. 1990. https: //doi.org/ 10.1111/j.1949-8594.1990.tb12046.x 
[40] Santos, V, A., \& Arroio, A. "The representational levels: Influences and contribution to research chemical education", Journal of Tukish Science Education, vol.13, no.1, pp. 3-18. 2016. https://www.tused.org.

[41] Aceng,H, Sumantri,M.S., \& Priyono , "The Effect of Instructional Models and Mathematical Logic Intelligence toward the Basic Chemistry Learning Outcomes by Controlling Student's Initial Competence," Universal Journal of Educational Research, Vol. 8, No. 3, pp. 960 - 970, 2020. DOI: 10.13189/ujer.2020.080331.

[42] Wahyudiati, D. "Pengembangan perangkat pembelajaran berorientasi model pembelajaran diskusi pada pokok bahasan energi dan perubahannya untuk menumbuhkan sikap ilmiah siswa", Badan Penelitian dan Pengembangan, 2010. pp.30-50.

[43] Ucu, C, Yuli, R, Maria P, Sasmoko, Ahman, Jujuk F., \& Agus D, "Ethnopedagogy Integration with Mobile Learning to Improve Students' Learning Achievement in Remote Areas," Universal Journal of Educational Research, Vol. 8, No. 5, pp. 1687 - 1697, 2020. DOI: 10.13189/ujer.2020.080 505.

[44] Ismiani, S., Syukri., \& Wahyudiati, D. "Pengaruh penerapan metode problem based learning terhadap sikap ilmiah dan hasil belajar biologi siswa kelas VII MTS nw 01 kembang kerang", Biota, vol.10, no.1. pp.68-75. 2017. https://biota.ac.id/index.php/jb/article/view/27.

[45] Wahyudiati, D. "Analisis efektivitas kegiatan praktikum sebagai upaya peningkatan hasil belajar mahaisswa", Jurnal Tastqif, vol 14, no. 2, pp.143-168. 2016. https://journal.uin mataram.ac.id/index.php/tatsqif.

[46] Fadli, A \& Masnun. "The Earthquake Risk Management Model based on Sasak' Local Wisdom", Disaster Advances. vol. 13, no.3. pp. 54-61. 2020. https://www.journalguide.co $\mathrm{m} /$ journals/disaster-advances. 